\title{
Preparing pre-service teachers to make connections between science and en- gineering concepts through teamwork with engineering students (RTP, Strand 1)
}

\section{Dr. Jennifer Melander, University of Nebraska, Lincoln}

Jenny Melander is an Assistant Professor of Biological Systems Engineering and Science Literacy Specialist in the Institute of Agriculture and Natural Resources at the University of Nebraska-Lincoln. She is also the coordinator for the National Center for Agricultural Literacy. She is active in promoting science and engineering education in both formal and informal settings through her research, extension, and outreach activities. Dr. Melander is actively engaged in several cross-disciplinary regional and national efforts related to STEM education and outreach. Most recently, she was part of a team that received NSF funding to engage youth in STEM through wearable technologies. She is also involved in organizing and promoting FIRST Lego League and FIRST Tech Challenge robotics competitions.

\section{Dr. Krista Lynn Adams, University of Nebraska - Lincoln}

Dr. Krista L. Adams is an Assistant Professor of Science Education at the University of Nebraska - Lincoln. She completed her PhD at Arizona State University and was a member of the first cohort of Sandra K. Abell Institute participants in 2009. Krista taught middle school physical science and is a National Board Certified Teacher now studying novice teachers' decisions based on the design and implementation of their teaching practices. 


\section{Preparing Pre-service Teachers to Make Connections Between Science and Engineering Concepts Through Teamwork with Engineering Students (RTP, Strand 1)}

Abstract

NGSS has called for the inclusion of engineering in K-12 classrooms. This has shifted the emphasis from a discipline-based focus to crosscutting concepts that connect many disciplines. These crosscutting concepts, such as systems and system models, promote a deeper understanding of science and engineering concepts. Traditional education programs often do not prepare teachers to build these connections between science and engineering concepts. The objective of this study was to determine if formal interactions with engineering students to facilitate afterschool science clubs would provide a means for pre-service teachers to learn how to make these connections in their instructional practices.

In this study, undergraduate elementary education and biological systems engineering students worked together to plan and facilitate afterschool science clubs. The data suggests that the preservice teachers were able to develop instruction that emphasized various crosscutting concepts; began to make connections to science and engineering concepts; and discussed the importance of collaborations with scientists and engineers for their future classrooms. The results of this study show that formal interactions with engineering students better prepares pre-service teachers by improving their ability to make connections between science and engineering concepts. The collaboration supports the development of unique ways to incorporate science and engineering in their instructional practices. These results will lead to a better understanding of how to prepare pre-service teachers to integrate crosscutting science and engineering concepts into their classrooms.

\section{Introduction}

Key to an effective science teacher is the use of a reform-based instruction. These practices engage students to move beyond observing, collecting data and forming conclusions to involving students in how science and engineering is done by relating concepts to both real-world applications and personal interests ${ }^{[1]}$. As a result, emphasis has shifted from a discipline-based focus on isolated facts to crosscutting concepts that connect many disciplines. Crosscutting concepts, such as systems and system models, promote a deeper understanding of science and engineering concepts. In contrast to subject specific teaching preparation, as is commonly found in secondary teacher preparation programs, developing the skills to teach all subjects is often overwhelming for individuals preparing to teach younger students.

Engineering provides a framework to apply math and science through problem solving. The National Academy of Engineering describes how engineers "constantly discover how to improve our lives by creating bold new solutions that connect science to life in unexpected, forwardthinking ways ${ }^{[2]}$ ". Students develop a variety of skills, including problem solving, creativity, communication, leadership and teamwork through practicing engineering in elementary school, 
${ }^{[3]}$. These engineering practices are grounded in the engineering design process. In addition, the sketching and brainstorming process of developing a solution assists the students in developing systems thinking ${ }^{[4]}$. Engineering design, particularly at lower grade levels, is essentially science driven problem solving. The development of these skills is tied to their successes throughout their academic careers and in their everyday lives. In addition, these engineering concepts help students discover the crosscutting themes between the traditional science disciplines.

Research has found a direct correlation between student achievement and teacher preparedness to teach science ${ }^{[5]}$. Teacher's subject matter knowledge influences the instruction implemented in the classroom ${ }^{[6]}$. However, research on pre-service and in-service elementary teachers ${ }^{[7]}$ has found that they hold a similar level of science understanding as elementary students ${ }^{[8]}$. In order to support the teacher learner, preservice elementary teachers need opportunities to engage in rich experiences that confront and challenge their practices and beliefs about teaching science ${ }^{[9]}$. Introducing engineering practices may provide "an opportunity to model unfamiliar pedagogies, approaches that may be at odds with current educational fashion ${ }^{[10]}$." Collaborating with undergraduate engineering students to design and implement instruction may provide support for pre-service teachers.

The objective of this study was to determine if formal interactions with engineering students to facilitate afterschool science clubs would provide a means for pre-service elementary teachers to learn how to make connections between science and engineering concepts. In the present study, the emphasis will be on understanding the connections through the developed and implemented instructional strategies and teacher reflections on the experiences during the elementary science methods course. The following questions guide this study:

- How does the collaboration between engineering students and pre-service teachers impact the subject matter knowledge needed to design and implement instruction for science and engineering?

- What are the affordances and constraints that pre-service teachers' identify as impacting the process of designing and implementing instruction for science and engineering?

\section{Literature}

Teacher preparation is a time for the teacher to learn how to teach. Science education researchers agree that preservice teachers need to enter the classroom with what Shulman ${ }^{[11]}$ calls as the "subject matter for teaching." This involves knowing about the discipline of science including the concepts and strategies of inquiry ${ }^{[12-16]}$; as domain-specific in which a chemistry laboratory would use an observable reaction to understand the phenomenon ${ }^{[17,18]}$; and as topic-specific for example the key ideas and concepts about solids, liquids and gases ${ }^{[19,20]}$. This knowledge enables the teacher to transform his or her academic knowledge to that of a knowledge based on the needs and interests of the students. Research has discussed that the transformation of knowledge is gained through experience working within the classroom setting ${ }^{[16,19,21]}$. However, pre-service elementary teachers do not have the same amount of opportunities to teach science as their secondary counterparts prior to entering the classroom.

Influencing the development of instructional strategies is the teachers' subject matter knowledge (SMK). This includes the teacher's knowledge of the facts, theories, and laws associated with their content area, as well as how knowledge is developed in the disciplinary field (e.g., science). 
For this study, SMK will also encompass the teacher's knowledge of engineering practices. The process of teaching and learning involves the teacher selecting topics that make sense to him or her but decisions are also situated in the needs and interests of their students. In doing so teachers need to be aware of the students' needs and understandings when planning how to represent the content $^{[16]}$.

The Next Generation Science Standards (NGSS) ${ }^{[22]}$ integrate engineering design into science education instruction. The NGSS describes engineering design as including: identification of the problem and associated constraints and criteria; the design of multiple solutions to the problem that addresses the constraints within the problem; and finally, optimization of the design solution through testing and refining the final design best suited for the problem. Within the engineering practices, NGSS identified grade spans in which to engage children in engineering practices. At the K-2 grade span children are introduced to problems that people want to change. As the children grow, the engineering practices shift to include the children in defining problems and designing solutions.

Children have a natural tendency to be curious, create and design ${ }^{[23]}$. Educators can build off of this natural tendency in the classroom ${ }^{[3]}$. It is important to emphasize that including engineering in elementary education doesn't mean adding extra material to the curriculum, but instead provides a framework to connect the STEM (Science, Technology, Engineering and Mathematics) disciplines ${ }^{[3]}$. Mann et al. ${ }^{[3]}$ note in their discussion of engineering concepts in curriculum that many engineering tools such as mathematics are present in traditional concept areas "but seldom are recognized as engineering." In addition, engineering emphasizes skills such as "asking questions and defining problems" and "developing and using models" that can be applied to a variety of concept areas ${ }^{[23]}$.

This applicability of the engineering framework to multiple concept areas provides a powerful reason for including engineering in early education, however engineering is not often taught to pre-service educators. Studies have shown that educators feel uncomfortable incorporating engineering design into their classrooms even after participating in professional development trainings ${ }^{[10,24]}$. Beyond the fact that they are unfamiliar with engineering practices, educators are often nervous about the messiness and open-endedness of engineering design problems in the classroom ${ }^{[3]}$. Engineering problems by their very nature will result in multiple 'correct' answers ${ }^{[10]}$. Educators are surprised by the creativity of their students and the wide range of solutions they create ${ }^{[24]}$. This open-endedness can result in the teacher moving from a leadership role to more of a co-participant and co-researcher with his/her students ${ }^{[24]}$. This change in roles can add to their discomfort. Despite these difficulties, it is possible to engage elementary educators in engineering practices. Research suggests that to support teachers in learning engineering design they need to experience design firsthand ${ }^{[10]}$.

Research on the collaboration between teachers and scientists have shown to build students and teachers knowledge of science content and processes. Houseal, Abd-El-Khalick and Destefano ${ }^{[25]}$ recognized that the teachers actually play two roles in the collaborations. The teachers take on the role of a student to learn about science practices and the role of a teacher to transform the knowledge to pedagogical strategies. These scientist/teacher collaborations provide authentic, inquiry-based learning which provide teachers insight into the scientific community ${ }^{[26,27]}$ and 
content knowledge ${ }^{[28]}$. However, elementary teachers have difficulty aligning the planned and enacted instruction $^{[29]}$.

There are identified challenges to science-teacher collaborations. Houseal et al. ${ }^{[25]}$ discussed five such challenges often faced by collaborations "(a) content knowledge background needs of teachers and scientists, (b) accuracy and relevance of student data, (c) securing and negotiating resources for both scientists and teachers (materials, time, and personnel), (d) communication needs and barriers, and (e) outside factors affecting both the educational and research communities". For this study, we were only concerned with the content knowledge of the two groups and the communication needs and barriers. To address these challenges, a review of the literature by Houseal et al. suggests (a) considering hierarchical issues and power imbalances between all parties; (b) frequent and open communication; (c) the need for all parties to be in on the design of the activities; (d) active development of long-term commitment to the collaboration and (e) a third-party liaison to act as a facilitator to help with the interactions. These considerations were part of the design of this project as discussed in the methods section.

\section{Methods}

The participants in this study were enrolled in an elementary science methods course offered at a Mid-West university taught by the first author. Participants signed a consent form approved by the Internal Review Board, which was placed in a closed envelope to be opened at the end of the course to ensure that there was no impact to student scores or difference in treatment. For this study, all pre-service teachers $(n=30)$ enrolled in the course signed consent forms to participate. The participants were primarily Caucasian female from the Mid-West United States majoring in elementary education. The terms education student and pre-service teacher will be used throughout the paper. Education student will be used in conjunction with discussions about the engineering student; otherwise the term pre-service teacher will be used.

Students in the senior-level elementary science methods course were placed on teams with students in a junior-level biomedical engineering survey course taught by the second author. The third-party liaisons for this collaboration were the first and second authors as we discussed individually with our students within the course and as a group when the two groups worked together. Students worked on teams to design and implement club activities to elementary students in local Community Learning Centers (CLCs) over 6-7 weeks. The CLC programs target low-socioeconomic schools that are underperforming in science on local and state tests.

The elementary science methods course covers the subject matter knowledge for teaching science and engineering skills using the 5-E learning cycle ${ }^{[30]}$ - Engage, Explore, Explain, Elaborate, and Evaluate. The course consists of designing and implementing a science lesson plan for K-5 ${ }^{\text {th }}$ grade students using a modified Content Representations ${ }^{[31]}$ (CoRe) lesson form, participating in exemplar lessons demonstrating science and engineering practices, and classroom discussions on teaching science. The engineering course covers a wide-range of biomedical engineering topics (biomaterials, bioinformatics, imaging, etc.). This course consists of lectures, guest speakers, class discussion, labs and field trips. The two courses met on differing university campuses except for the initial meeting to introduce the project. 
At the initial student meeting, the instructors reviewed the project guidelines for both the engineering and elementary students. Students self-selected groups based on their availability during the week and grade-range preference (e.g., K-2, 3-5). A typical group included 5-6 education students and 6-8 engineering students. There were five different science clubs run by teams of education and engineer students that worked with an average of 15 children. The instructors provided GEMS ${ }^{[32]}$ Teacher Guides to guide topic choice (e.g., Bubble Festival, Ladybugs, Electric Circuits). At the conclusion of this meeting, groups were required to identify a science club name and activity theme, as well as share contact information. Students were expected to communicate on their own time after this first meeting. Teams were instructed to work together to develop instruction capitalizing on each other's strengths. Specifically, the preservice teachers brought their knowledge of education standards (NGSS and Common Core) and expertise working with children. The engineering students were experts in engineering and science content and connections between the two disciplines.

The assumption of the instructors was that the teachers and engineering students would be able to collaborate without additional class time to meet. To follow the collaborations, the instructors dedicated class time to discuss concerns and successes with each group of students separately, how to handle difficulties in communications, and what and when lessons would be taught. The instructors met regularly to discuss the concerns and successes shared by the students. The engineers and teachers responded to specific open-ended check-in questions throughout the duration of the semester collaboration.

A typical club lasted 6-7 weeks meeting once a week with the first 4-5 meetings led by the preservice teachers. The pre-service teachers were responsible for preparing and implementing lessons over the entire length of the program, while the engineering students provided science content resources for the education students. In addition, the engineering students were required to develop and implement a culminating project relating engineering to the science concepts for the CLC children. The education students served as pedagogical resources for the engineering students in designing the culminating project.

The pre-service teachers were assessed throughout the project on their development and reflection of the implemented instructional strategies; attitudes towards the project; and development of communication skills with the engineering students and elementary children. Each student was responsible for planning a modified CoRe lesson which identified: the grade level expectations (e.g., state science standards); big idea for the lesson (e.g., life cycle of a penguin); importance for children learning the topic; background knowledge needed to for the lesson including identified common misconceptions children may hold; specific activities for each of the engage, explore, explain and elaborate phases; and the assessment of students' understanding. After teaching the lesson, the students were asked to write a brief summary of the lesson, impact on student learning, and identify areas in which the lesson could be changed or improved.

Open-ended class check-in questions were used to capture the progress and the impact on collaboration between the two groups. The first check-in questions were administered two weeks after meeting with the engineering students for the first time. The questions focused on how the collaborations were going and what the pre-service teachers were doing to support 
communication between the two groups. The second check-in was administered three weeks later to determine what the pre-service teachers were learning from their teaching experience or what they were looking forward to when they taught their lesson. The final question asked students to describe what they were learning from the collaborations with the engineers.

Students participated in focus group interviews as a form of supplementary data. Focus group interviews rely on the interactions between participants to generate data, which allows for participants to explore the topic in depth ${ }^{[33]}$. There were a total of 5 focus groups with 6 preservice teachers per group. There were at least one representative from each science club in a group. The questions focused on what the pre-service teachers learned about thinking like a scientist and engineer; the purpose of the collaborations with the engineers; definition of success of the science clubs; and solutions implemented to support communication. Each interview was conducted in person and recorded using an audio recording iPhone mobile application. Each focus group interview was transcribed from the recording for the use of qualitative analysis to determine the impact on pre-service teachers' knowledge of teaching and learning science and engineering practices.

Finally, the culminating project for the elementary science methods course asked the pre-service teachers to reflect on the experiences provided by the course in relation to his or her growth in relation to the course goals. The six course goals were:

- Demonstrate understanding of the central concepts (content), tools of inquiry (process skills), and structure of science (the nature of science);

- Demonstrate understanding of the social, intellectual, and personal development of students and recognize the diverse needs, interests, and abilities of students;

- Demonstrate knowledge of and ability to critically evaluate and utilize contemporary science standards (state and national) and curriculum materials for science education;

- Demonstrate knowledge of and ability to plan and implement a variety of instructional strategies and assessment techniques for teaching science at the elementary level;

- Demonstrate the capacity to create a positive environment that encourages science learning by modeling the attitudes and dispositions of scientific inquiry;

- Demonstrate the capacity for collegiality, reflective practice, and professional growth in regard to science teaching.

The students were asked to reflect on any activity, experience, or reading with respect to teaching and learning science and engineering to demonstrate growth. The projects addressed the goals separately requiring specific evidence to support the students' discussion of growth for teaching and learning science and engineering. Each project was usually 10 pages typed, included pictures, course projects, and support from the course readings. Responses that referenced the CLCs or collaborating with engineers were used as supplementary data to determine the impact of the collaborations to support the pre-service teacher's growth. Of the 30 students, only 7 students mentioned the collaborations and working in the CLCs as impacting their knowledge of teaching and learning science and engineering.

Data analysis. The qualitative analysis consisted of reading the corpus of data collectively to answer what is the impact to undergraduate elementary pre-service teachers' instructional practices working collectively with undergraduate engineering students. After reading all responses, the qualitative data were coded based on the conceptual framework ${ }^{[34]}$ which for this 
study was based on the knowledge of instructional strategies. The initial category codes were teachers' knowledge of instructional strategies and crosscutting concepts. After the initial coding, we found the codes could be further described by the affordances and constraints to the teaching and learning engineering practices.

Each data source provided a different aspect of the impact of collaborating with engineering students. The CoRe document reflection represented the teachers' considerations for developing and implementing instructional strategies; the open-ended class check-in questions determined the impact of working with the engineering students, the focus group interviews answered how the pre-service teachers described their understanding of how to teach engineering and science content; and finally, the culminating project determined how pre-service teachers' viewed the collaborations to his or her own growth in teaching and learning science engineering. The data were triangulated to determine how pre-service teachers' described and enacted engineering and science content. The data were analyzed using the NVivo 9 qualitative research tool to allow for the organization of multiple codes across various documents.

Results

This project studies the impact of collaborations between education and engineering students on the design and implementation of instructional strategies in terms of science and engineering concepts. The pre-service teachers designed and implemented instruction as part of an after school science club.

Crosscutting concepts bridging science and engineering. The engineering and pre-service teachers were asked to determine how the given topics related to biomedical engineering. The engineering students completed the list prior to meeting and the education students were asked to give additional ideas with the final list (See Table 1).

Table 1.

Topics link to biomedical engineering

\begin{tabular}{ll}
\hline \multicolumn{1}{c}{ GEMS Teacher's Guide } & \multicolumn{1}{c}{ Potential Tie to Biomedical Engineering } \\
\hline Lady Bugs & Biomechanics/brushbots \\
Matter & Biomaterials \\
Schoolyard Ecology & Microbial Ecology \\
Living with a Star & Building Space Suits \\
Penguins and their young & Thermodynamics, hypothermia \\
Bubble Festival & Material properties, Cells \\
Electric Circuits & ECG, electrical devices \\
Cabbage and Chemistry & Biosensors, Blood pH \\
Stories in Stone & Biomaterials, kidney \\
Ocean Currents & Blood flow \\
Oobleck & Muscle fibers/reflexes \\
\hline
\end{tabular}

The education and engineering students worked together to choose a science club topic. Instruction was designed to address a variety of big ideas and relating crosscutting concepts to bridge disciplinary boundaries in science and engineering (see Table 2). The groups focused on multiple crosscutting concepts within the science club. For example, the Penguin Plunge and A 
Bugs Life groups focused on the Structure and Function and Energy and Matter crosscutting concepts. Both groups studied the Structure and Function of the unique features of the animals to explain the adaption for the habitat and other features to perform daily functions. For Energy and Matter, the two groups designed instruction to explore how "animals obtain food they need from plants or animals ${ }^{[1]}$,.

Table 2.

Science Club names, big ideas and crosscutting concepts

\begin{tabular}{|c|c|c|}
\hline $\begin{array}{l}\text { Science Club } \\
\text { (Grade level) }\end{array}$ & Big Idea & Crosscutting Concepts \\
\hline $\begin{array}{l}\text { Bubble Buddies } \\
\left.\text { (K-2 } 2^{\text {nd }} \text { grade }\right)\end{array}$ & Properties of bubbles & $\begin{array}{l}\text { Structure and function; } \\
\text { Systems and system models }\end{array}$ \\
\hline $\begin{array}{l}\text { Penguin Plunge } \\
\left(\mathrm{K}-2^{\text {nd }} \text { grade }\right)\end{array}$ & Life cycle of penguins & $\begin{array}{l}\text { Structure and function; Energy } \\
\text { and matter }\end{array}$ \\
\hline $\begin{array}{l}\text { Shocking Secrets! } \\
\left(2^{\text {nd }}-3^{\text {rd }} \text { grade }\right)\end{array}$ & Electricity & Energy and matter \\
\hline $\begin{array}{l}\text { A Bugs Life } \\
\left(\mathrm{K}-1^{\text {st }} \text { grade }\right)\end{array}$ & Life cycle of ladybugs: & $\begin{array}{l}\text { Structure and function; Energy } \\
\text { and matter }\end{array}$ \\
\hline $\begin{array}{l}\text { Chemical Transformers } \\
\qquad\left(3^{\text {rd }}-5^{\text {th }} \text { grade }\right)\end{array}$ & $\begin{array}{l}\text { Physical and chemical } \\
\text { changes }\end{array}$ & $\begin{array}{l}\text { Cause and effect; Energy and } \\
\text { matter }\end{array}$ \\
\hline
\end{tabular}

The groups' final CoRe lessons included connections to engineering, science and technology (See Table 2). Only one group was found to connect the crosscutting ideas to science and engineering. Chemical Transformers developed and taught a final CoRe lesson that engaged children in engineering practices related to physical properties. The children explored the impact of protective headgear when bicycling or skating by engaging children to design a protective helmet then connected that to physical changes. The children were asked to develop a container to protect a raw egg from cracking when dropped. If the egg cracked, this would represent a physical change.

Two groups - Bubble Buddies and Penguin Plunge - focused on science content rather than engineering. Bubble Buddies connected the properties of bubbles to cells; Penguin Plunge explored the life cycles of penguins. Two groups' final CoRe lesson projects connected the science concepts to technology applications. The Shocking Secrets! - ECG and Lie Detector and A Bugs Life - brushbots - engaged children in exploring the science concepts in relation to technology applications.

Pre-service teachers' knowledge of science and engineering. In this pilot study, the collaborations supported the understanding of the science concepts rather than engineering. We found that two collaborative groups discussed specific impacts of the collaboration to the preservice teachers designed instruction. The pre-service teachers held a limited knowledge of engineering concepts. The Shocking Secrets! and the Bubble Buddies pre-service teachers discussed how the engineers supported instruction. 
The Shocking Secrets! group worked closely with one engineering student during the implementation of the instructional strategies. The specific engineering student chose to attend each club meeting while the education students were teaching. The pre-service teachers were able to ask specific questions about the content as questions arose. For example, one pre-service teacher shared

I depended a lot on my fellow classmates to learn about electricity. During the first lesson, I realized that was a huge asset. He was able to answer all of our questions and was an extra set of hands in the classroom.

Other engineering students attended the club while the education students' taught, but only the members of the Shocking Secrets! discussed the impact on instruction.

Unlike the Shocking Secrets!, the Bubble Buddies discussed needing more support for making connections between bubble properties and cells. For example, one pre-service teacher discussed I think it would have been helpful to have a little insight with from [sic] the engineers of how they were going to connect it so I could have incorporated more about the big idea in my lesson. I think one way I would have changed around the content would have been to have them thinking about if the shapes mattered of the bubbles mattered or if "bubbles" in our bodies were only circles.

This group often discussed that they were afraid that the children would have difficulty making the connection between the cells and bubbles without explicit instruction. As a result the instruction implemented by this group often included direct instruction of the connections between the two concepts.

The pre-service teachers asked at the end of the collaboration what they learned about thinking like a scientist/engineer from the collaboration. During focus groups, the consensus by the students was that they did not learn to think as an engineer. Instead, they learned more about how to think like a scientist and how to present information that was reform-based through the elementary science methods course. The education students recognized that the engineering students provided a unique perspective to the topics, but they were not able to make connections outside of the course collaborations. For the education students, it was hard to coordinate with the engineering students.

Even after collaborating with the engineering students, the pre-service teachers did not understand how the topics related to engineering. The pre-service teachers held a limited understanding of what engineering entailed which impacted their ability to connect science and engineering content. For example within the second check-in responses, a pre-service teacher from the A Bugs Life stated, "our lesson is about ladybugs. It's something that everyone knows. I don't know where their expertise comes into play."

Pre-service teachers' development of teaching and learning. Determining the topic and activities involved a negotiation between the engineering students' knowledge of the content and activities and the pre-service teachers' knowledge of appropriate content and activities for children. This collaboration was viewed as an advantage for the pre-service teachers. Working with the engineering students allowed for a different perspective on the content; provided a deeper, broader and integrated knowledge of the topic; and unique activities to represent the content. Several pre-service teachers discussed these same topics as a concern. These students discussed 
that the engineers did not understand what was age-appropriate in terms of content and instructional strategies discussed were a safety concern. For example, one student stated in her first check-in that

They [the engineers] do not necessarily know what is appropriate to use in a fifth-grade after school science club. For example, one experiment they want to conduct involved dry ice which not only isn't the easiest to obtain but difficult to work with in a short period of time.

The majority of the groups did not discuss how the collaboration with the engineering students impacted specific instructional strategies. Instead, they discussed the difficulty with working with the engineering students. This idea will be further discussed as part of the affordances and constraints to the development of pre-service teachers' knowledge of teaching and learning. Only the Bubble Buddies group designed and implemented instruction that was directly influenced by the interactions with the engineering students. The group connected the properties of bubbles to cells. The objectives for the CoRe lessons included the following:

- Students will be able to see how soap bubbles and body cells are similar in shape.

- They will be able to see how the shape of the bubbles/cells can change when they are touching one another.

- They will be able to explain how the shapes of bubbles/cells can protect.

- Students will also begin to develop an understanding of the connection between bubbles and living cells through group discussion and questioning.

- This lesson relates bubble colors to the different colors of cells in different living things.

The Bubble Buddies developed and implemented instructional strategies aligned with the objectives. The pre-service teachers implemented activities that explored the properties of bubbles and connected those ideas to cells. For example, one activity involved the children exploring the colors of bubbles. The pre-service teachers then shared pictures of plant and animal cells to help children understand the connections between bubbles and cells. In another example, the students encouraged children to pop bubbles with their fingers. The activity was explained as a model of how a virus acts on a cell membrane. This example shows how the students were able to make connections between scientific concepts. The model was used to connect the properties of bubbles to cell membranes allowing for a deeper and more contextualized experience for the children.

Constraints and affordances impacting pre-service teachers' knowledge of teaching and learning engineering. The education students recognized specific constraints and affordances from working with the engineering students. Constraints focused on the difficulty to communicate with the engineering students in terms of what engineers do and not understanding content connections. The pre-service teachers discussed the ease of finding resources and ability to address children's stereotypical views as affordances.

Across all data forms, the education students discussed constraints to the collaboration with the engineering students. Communication barriers were seen as a primary constraint to the collaborations. The education students discussed that by not understanding what the engineers did made it difficult to understand some of their ideas for teaching topics. As one pre-service 
teacher shared in the second check-in, "I struggled thinking of things to talk about that the engineers would know a lot about because of the lack of information I had about what they actually did." By understanding what the engineers did, the students discussed it might help to do a better job in developing the science club experiences as they could plan activities to connect to engineering.

The other most discussed barrier was the language differences. The pre-service teachers recognized there are differences in the language used to communicate information. The engineering students discussed laboratory experiments and content; the pre-service teachers discussed the abilities of children and how to plan lessons. As one student discussed in the first check-in, "our jargon is foreign to them and their jargon is foreign to us." The language difference between the engineers and the children was also a concern. The pre-service teachers were concern about using terminology appropriate for the elementary classroom. One student shared in the first check-in that the engineering students "have never taught and they don't know how to "dumb" down their language" for the children. In order to address the barrier, the preservice teachers believed the engineering students should spend more time in the after school classroom. For example, one student stated in the culminating project that "after working with the engineers I realized that not everyone has had this experience and that not everyone knows how to bring down the language so that it is easier for a child to understand."

Even with the constraints caused by communication differences the pre-service teachers recognized the experience as an affordance. The pre-service teachers discussed differences in communication would be something they would experience in the work setting. For example, one pre-service teacher discussed in her culminating project "The overall experience has shown me just how important communication, collaboration, and accountability can be and it has certainly encouraged me to communicate more effectively with those around me in my future career setting."

The pre-service teachers recognized that the engineering students provided affordances for his or her future classroom. From the collaboration, the pre-service teachers discussed the importance of incorporating outside resources in the classroom. The engineers were seen to provide a different perspective on science. As one student discussed "I have learned there are great resources out in the community that can be brought into the classroom to provide students with an even better science education." Another pre-service teacher discussed that seeking out local resources was important to the teacher "because I think often times we forget who and what's all out there."

Another affordance identified was the ability to address children's stereotypic views of scientists. The first activity in the education science methods course was to use the Chamber's ${ }^{[35]}$ task to Draw-a-scientist and read the Bodzin and Gehringer ${ }^{[36]}$ article on Breaking Science Stereotypes. The drawings by the students were male, primarily a chemist, and represented mythical features of a scientist - representing Einstein type features of crazy hair. Most engineering students did not attend the science club until the last two meetings of the after school science club which was about 12 weeks later. A few pre-service teachers discussed the impact of the collaboration as helping children address stereotypical views. For one pre-service teacher, he wrote in his culminating project that he was still confronting his stereotypical views with the children in the science club near the end of the semester. He stated 
A bunch of the engineering students came in to teach what they had come up with. Immediately the students were amazed that there were girls there, and that they weren't wearing lab coats! It turns out I had the same stereotypes as five and six year olds. I am glad I experienced this because if I am not careful, I could pass my own stereotypes onto my students.

\section{Discussion and Conclusion}

The purpose of this study was to determine the impact of collaborations between elementary education and engineering students on the subject matter knowledge for teaching science and engineering content. Results from this pilot study indicate that preservice elementary teachers need support to understand engineering content as well as to design and implement instruction that connects science and engineering concepts and incorporates engineering practices. Missing from their instruction was attention to engineering practices such as testing designs, redesigning, and communicating results. According to Darling Hammond ${ }^{[37]}$, elementary teachers must understand the content in order to promote learning the content. In this study, the teachers discussed that developing instruction was difficult because they did not understand engineer roles and engineering practices. Collaborations with undergraduate STEM specialists require more structured discussions and experiences with the pre-service teachers to understand STEM content for teaching.

Moore ${ }^{[9]}$ discussed that pre-service elementary teachers need opportunities to engage in rich experiences that confront and challenge their practices and beliefs about teaching science. Our study supports this finding. The pre-service teachers more purposefully designed and implemented instruction to address differences as they perceived more dissonance between the science content and the culminating project. While all groups developed instruction that connected science to technology and engineering practices, two groups highlighted the unique connections with the science topic. When culminating projects did not appear to relate to biomedical engineering and/or biology concepts, pre-service teachers were less likely to explicitly develop and discuss instruction to help students see the connections. However, other factors may have impacted the instruction implemented. Our results suggest that crossdisciplinary activities between elementary education and engineering students can support the development of instruction connecting the unique perspective of the engineering students.

Communication difficulties with the engineering students hindered the development of subject matter knowledge and instruction strategies promoting engineering practices. Like Houseal et al. ${ }^{[25]}$, communication was a challenge between the pre-service elementary teachers and engineering students. Using jargon that was unique to the individual group - education or engineering - hindered communication as a collaborative group. The pre-service teachers recognized that by not understanding the science and engineering content jargon they were unable to use the information to adjust their instruction. Establishing common experiences that the two groups can build from could address communication difficulties. 
Data from the current study were used to inform the development of subsequent elementary science methods collaborations with the engineering faculty and students. Specifically, the initial meetings between the pre-service elementary teachers and the engineering students were restructured to build a common knowledge base focusing on their K-16 experiences learning STEM and perspectives on teaching STEM.

Implications for science teacher education

Results from this study offer insights on how to build preservice programs to promote the development of crosscutting concepts and engineering practices. Engaging in discussions with STEM undergraduate students presents an opportunity to build pre-service teachers' subject matter knowledge for teaching. These collaborations may prove useful in helping teachers identify areas and practices in which they could improve and areas were they excel. The development and implementation of science and engineering instructional strategies by the education and engineering students could strengthen course instruction and better align instructor classroom practices with course goals and science education reform documents.

Acknowledgments

We would like to thank the local CLC Site Coordinators for providing access to their afterschool programs and being flexible to accommodate our student's schedules.

References

1. National Research Council, A Framework for K-12 Science Education: Practices, Crosscutting Concepts, and Core Ideas. 2011, Washington, DC: National Academies Press.

2. National Academy of Engineering, Messaging for engineering: From research to action. 2013, Washington DC: National Academies Press.

3. Mann, E.L., et al., Integrating engineering into K-6 curriculum: Developing talent in the STEM disciplines. Journal of Advanced Academics, 2011. 22(4): p. 639-685.

4. Lammi, M. and K. Becker, Engineering design thinking. Journal of Technology Education, 2013. 24(2): p. 55-77.

5. Darling-Hammond, L. and P. Youngs, Defining "highly qualified teachers": What does "scientificallybased research" actually tell us? Educational Researcher, 2002. 31(9): p. 13-25.

6. Kind, V., A conflict in your head: An exploration of trainee science teachers' subject matter knowledge development and its impact on teacher self-confidence. International Journal of Science Education, 2009. 31: p. 1529-1562.

7. Krall, R.M., K.H. Lott, and C.L. Wymer, Inservice elementary and middle school teachers' conceptions of photosynthesis and respiration. Journal of Science Teacher Education, 2009. 20: p. 41-55.

8. Rice, D.C., I didn't know oxygen could boil! What preservice and inservice elementary teachers' answers to 'simple' science questions reveals about their subject matter knowledge. International Journal of Science Education, 2005. 27: p. 1059-1082.

9. Moore, F.M., Preparing preservice teachers for urban elementary science classrooms: Challenging cultural biases toward diverse students. Journal of Science Teacher Education, 2008. 19: p. 85-109.

10. Cunningham, C.M. and W.S. Carlsen, Teaching engineering practices. Journal of Science Teacher Education, 2014. 25: p. 197-210. 
11. Shulman, L.S., Those who understand: Knowledge growth in teaching. Educational Researcher, 1986.15 : p. 4-14.

12. Shulman, L.S., Knowledge and teaching: Foundation of the new reform. Harvard Educational Review, 1987. 57: p. 1-22.

13. Abell, S.K., Research on science teacher knowledge, in Handbook of research on science education, S.K. Abell and N.G. Lederman, Editors. 2007, Lawrence Erlbaum Associaties.: Mahwah, NJ. p. 1105-1150.

14. Park, S. and Y.-C. Chen, Mapping out the integration of the components of pedagogical content knowledge (PCK): Examples from high school biology classrooms. Journal of Research in Science Teaching, 2012. 49: p. 922-941.

15. Friedrichsen, P., et al., Does teaching experience matter? Examining biology teachers' prior knowledge for teaching in an alternative certification program. Journal of Research in Science Teaching, 2009. 46: p. 357-383.

16. Magnusson, S., J. Krajcik, and H. Borko, Nature, sources, and development of pedagogical content knowledge for science teaching, in Examining pedagogical content knowledge, J. Gess-Newsome and N.G. Lederman, Editors. 1999, Kluwer Academic Publishers: Dordrecht Netherlands. p. 95-132.

17. Veal, W.R. and D.S. Kubasko, Biology and geology teachers' domain'specific pedagogical content knowledge of evolution. Journal of Curriculum and Supervision, 2003. 18: p. 334-352.

18. Veal, W.R. and J.G. MaKinster Pedagogical content knowledge taxonomies. Electronic Journal of Science Education, 1999. 3.

19. Van Driel, J.H., O. de Jong, and N. Verloop, The development of preservice chemistry teachers' pedagogical content knowledge. Science Teacher Education, 2002. 86: p. 572-590.

20. Deng, Z., Knowing the subject matter of a secondary-school science subject. Journal of Curriculum Studies, 2007. 39: p. 503-535.

21. Grossman, P.L., The making of a teacher: Teacher knowledge \& teacher education. 1990, New York: Teachers College Press.

22. Council, N.R., Next Generation Science Standards: For States, By States. . 2013, Washington, DC: The National Academies Press.

23. Cunningham, C.M. and W.S. Carlsen, Precollege engineering education, in Handbook of Research on Science Education, N.G. Lederman and S.K. Abell, Editors. 2014, Routledge: New York, NY. p. 747-758.

24. Capobianco, B.M., Exploring a science teacher's uncertainty with integrating engineering design: An action research study. Journal of Science Teacher Education, 2011. 22: p. 645-660.

25. Houseal, A.K., F. Abd-El-Khalick, and L. Destefano, Impact of a student-teacher-scientist partnership on students' and teachers' content knowledge, attitudes toward science, and pedagogical practices. Journal of Research in Science Teaching, 2013. 51: p. 84-115.

26. Harnik, P.G. and R.M. Ross, Developing effective K-16 geoscience research partnerships. Journal of Geoscience Education, 2003. 51: p. 5-8.

27. Gosselin, D.C., R.H. Levy, and R.J. Bonnstetter, Using earth science research projects to develop collaborations between scientists at a research university and K-12 educators: Insights for future efforts. Journal of Geoscience Education, 2003. 51: p. 114-120.

28. Evans, C.A., et al., Student/scientist partnerships: A teachers' guide to evaluating the critical components. The American Biology Teacher, 2001. 63: p. 318-323.

29. Capobianco, B.M. and M. Rupp, STEM teachers' planned and enacted attempts at implementing engineering design-based instruction. School Science and Mathematics, 2014. 114: p. 258-270.

30. Bybee, R.W., et al., The BSCS 5E instructional model: Origins, Effectiveness, and applications. 2006: Colorado Springs, CO.

31. Loughran, J., A. Berry, and P. Mulhall, eds. Understanding and Developing Science Teachers' Pedagogical Content Knowledge. Professional Learning, ed. J.J. Loughran. Vol. 1. 2006, Sense Publishers: The Netherlands.

32. Great Explorations in Math and Science. [cited 2015 January 22]; Available from: http://www.lhsgems.org/gemsguides.html.

33. Hatch, J.A., Doing qualitative research in education settings. 2002, Albany, NY: State University of New York Press, Albany.

34. Miles, M.B. and A.M. Huberman, Qualitative data analysis: An expanded sourcebook. 2nd ed. 1994, Thousand Oaks, CA: SAGE Publications, Inc.

35. Chamber, D.W., Stereotypic images of scientists: The Draw-A-Scientist test. Science Education, 1983. 67: p. $255-265$. 
36. Bodzin, A. and M. Gehringer, Breaking science stereotypes. Science \& Children, 2001. 38(4): p. 36-41.

37. Darling-Hammond, L., Teacher quality and student achievement: A review of state policy evidence. Education Policy Analysis Archives, 2000. 8(1). 